\title{
The role of magnesium sulfate in prevention of seizures induced by pentylenetetrazole in rats
}

\author{
Luziene Dalmaschio Biasutti de Oliveira', \\ Roney Welinton Dias de Oliveira', \\ Henrique de Azevedo Futuro Neto², \\ Ester Miyuki Nakamura-Palacios ${ }^{1}$
}

\begin{abstract}
Magnesium sulfate $\left(\mathrm{MgSO}_{4}\right)$ has been used to prevent seizures in eclampsia. This study examined the central effects of $\mathrm{MgSO}_{4}$ on different types of pentylenetetrazole (PTZ)induced seizures. Male Wistar rats were submitted to intracerebroventricular (ICV) administration of $\mathrm{MgSO}_{4}$ at different doses followed by intraperitoneal administration of PTZ. The latency to the onset of the first seizure induced by PTZ was significantly increased by ICV administration of $\mathrm{MgSO}_{4}$ at a dose of $100 \mu \mathrm{g}$ compared to the control treatment. In addition, the total period during which animals presented with seizures was significantly reduced at this dose of $\mathrm{MgSO}_{4}$. Furthermore, the latency to the onset of the first partial complex seizure was significantly increased by the lowest dose of $\mathrm{MgSO}_{4}$. However, a high dose of $\mathrm{MgSO}_{4}$ had no effect or even potentiated the effect of PTZ. These results suggest that, depending on the dose, $\mathrm{MgSO}_{4}$ may be important in prevention of epileptic seizures. Key words: magnesium sulfate, seizures, experimental models, PTZ, rats.
\end{abstract}

\section{O papel do sulfato de magnésio na prevenção de crises induzidas por pentileno- tetrazol em ratos}

\section{RESUMO}

Sulfato de magnésio $\left(\mathrm{MgSO}_{4}\right)$ é utilizado para prevenir crises epilépticas na eclampsia. Este estudo examina os efeitos do $\mathrm{MgSO}_{4}$ em diferentes tipos de crise induzidas por pentilenotetrazol (PTZ). Ratos Wistar foram submetidos à administração intracerebroventricular (ICV) de diferentes doses de $\mathrm{MgSO}_{4}$ seguida de administração intraperitoneal de PTZ. A latência para o início da primeira crise induzida por PTZ foi aumentada pela administração ICV de $\mathrm{MgSO}_{4}$ na dose de $100 \mu \mathrm{g}$ quando comparada ao tratamento controle. Além disso, o período durante o qual os animais apresentaram crises foi reduzido com a mesma dose de $\mathrm{MgSO}_{4}$. A latência para o início da primeira crise parcial complexa também foi aumentada com a dose menor de $\mathrm{MgSO}_{4}(32 \mu \mathrm{g})$. No entanto, a maior dose $(320 \mu \mathrm{g})$ de $\mathrm{MgSO}_{4}$ não foi efetiva ou até potencializou os efeitos do PTZ. Esses resultados sugerem que, dependendo da dose, o $\mathrm{MgSO}_{4}$ pode ser útil na prevenção de crises epilépticas.

Palavras-chave: sulfato de magnésio, crises epilépticas, modelos experimentais, PTZ, ratos.

\author{
Correspondence \\ Luziene Dalmaschio Biasutti de Oliveira \\ Av. Marechal Campos 1468 \\ 29042-755 Vitória ES - Brasil \\ (E-mail: luzienedb@ig.com.br \\ palacios@npd.ufes.br
}

Received 25 August 2010

Received in final form 24 0ctober 2010 Accepted 1 November 2010
Defective synaptic function characterized by a reduction of gabaergic activity ${ }^{1}$ and/or an increase of glutamatergic activity has been suggested to play an im- portant role in epileptogenesis ${ }^{2,3}$. Almost current antiepileptic drugs mediate their actions through gabaergic receptors and voltage-gated sodium ${ }^{4}$ or calcium chan-

'Departamento de Ciências Fisiológicas, Centro de Ciências da Saúde, Universidade Federal do Espírito Santo, Vitória ES, Brazil; ${ }^{2}$ Departamento de Ciências Fisiológicas, Escola de Medicina da Santa Casa de Vitória. UNIVIX, Vitória ES, Brazil. 
nels ${ }^{5}$. Thus, a great effort has been made to find an effective and well-tolerated agent that can act at glutamatergic receptors ${ }^{6}$.

The activation of NMDA receptors appears to be associated with the initiation of a cascade of intracellular signaling events related to epileptogenesis, which subsequently become independent of NMDA receptor activation $^{2}$. Accordingly, it has been shown that NMDA antagonists are neuroprotective ${ }^{7}$ and may modify the progression of epilepsy in some experimental models of induced status epilepticus ${ }^{8}$.

It has been known that magnesium $\left(\mathrm{Mg}^{2+}\right)$ is involved in the pre- and post-synaptic events regulating the excitability of the central nervous system ${ }^{9}$, and these effects are mediated through the voltage-dependent blockade of NMDA receptors. This regulatory effect of $\mathrm{Mg}^{2+}$ on neuronal excitability may also involve its interference with calcium-mediated neurotransmitter release and the firing of cortical neurons ${ }^{10}$. There for magnesium sulfate $\left(\mathrm{MgSO}_{4}\right)$ may provide anticonvulsant activity by increasing the seizure threshold ${ }^{11}$.

Magnesium sulfate has been shown to be safe, effective and inexpensive for the prevention of seizures in women with pre-eclampsia and is considered the treatment of choice for eclampsia ${ }^{12}$. $\mathrm{MgSO}_{4}$ may also be useful in controlling seizures associated with conditions of glutamatemediated neurotoxicity with a high risk of symptomatic seizures, such as hypoxic-ischemic encephalopathy ${ }^{13}$.

Some studies have reported that low serum magnesium was related to epilepsy ${ }^{14,15}$. Yamamoto et al. ${ }^{16} \mathrm{ob}-$ served that children with seizures showed significantly lower concentrations of $\mathrm{Mg}^{2+}$ in cerebrospinal fluid compared to age-matched children.

More recently, a randomized, open-label, followup study suggested that combination treatment with ACTH plus $\mathrm{MgSO}_{4}$ must be more effective than $\mathrm{ACTH}$ monoterapy for infantile spasms ${ }^{17}$.

However, the effects of $\mathrm{MgSO}_{4}$ in experimental models of epilepsy have been controversial. $\mathrm{MgSO}_{4}$ administered systemically was ineffective on PTZ-induced seizures ${ }^{10,18}$. On the other hand, Mason et al. ${ }^{19}$ showed that $\mathrm{MgSO}_{4}$ administered intravenously decreased the total duration and increased the latency to onset of the convulsive activity. These authors suggested that $\mathrm{MgSO}_{4}$ was significantly more effective as a prophylactic agent than phenytoin ${ }^{19}$.

The present study examined the effects of ICV administration of $\mathrm{MgSO}_{4}$ on different types of PTZ-induced seizures with behavioral observations and simultaneous electroencephalographic recordings.

\section{METHOD}

32 male Wistar rats $( \pm 300 \mathrm{~g}, 2-3$ months old) were used. The animals were housed in cages with free access to food and tap water and were kept with a 12-h normal light-dark cycle, at a temperature controlled room.

Rats were anesthetized with chloral hydrate (400 $\mathrm{mg} / \mathrm{kg}$, ip) and positioned in a stereotaxic apparatus (Stoelting model 51600 IL, USA). An ICV cannula, internally protected with a stylus, was implanted in the lateral ventricle according to the following parameters from the bregma alignment: $\mathrm{B}=-0.3 \mathrm{~mm} \mathrm{AP},-1.3 \mathrm{~mm} \mathrm{~L},-4.0 \mathrm{~mm}$ $\mathrm{V}^{20}$. Two recording electrodes were soldered to stainless steel screws $(0.8 \times 1.8 \mathrm{~mm}$, MX-080-2FL, Small Parts Inc., FL, USA) fixed bilaterally to the skull. A third electrode was set as a reference pole, which was introduced subcutaneously into the posterior cervical region. Finally, the assembly of cannula and electrodes were anchored to the skull with dental acrylic and 4 small stainless steel screws. After the surgery, animals were housed individually in transparent Plexiglas ${ }^{\circledR}$ cages for 7 days to recover.

The care of all animal subjects in this study followed the ethical principles for animal experimentation from the Brazilian College in Animal Experimentation (COBEA), available at www.cobea.org.br.

An integrated system was used for electroencephalography (EEG) recording. The electrodes were anchored through a cable connection to an AC preamplifier (NL100 Neuro Log, Digitimer, UK). That was attached to the AC amplifier (NL 104), connected to filters (NL 126), and to an oscilloscope (Tektronic, USA, 205), which finally converged upon a signal digitizer (MP100 Biopac, USA). Signals derived from the bipolar electrodes between the left (PT1) and the right (PT2) parieto-temporal transitions were digitized and captured by electrophysiological software (Biopac, ACK 3.5, USA). Recordings took place for 40 minutes (interrupted only for drug administrations) for each experimental trial and were stored as individual files on a computer.

Magnesium sulfate $\left(\mathrm{MgSO}_{4}\right.$, Hypofarma, MG, BR) was diluted in saline (SAL, $0.9 \% \mathrm{NaCl}$ solution) for ICV administration at doses of 32,100 , or $320 \mu \mathrm{g}$. Pentylenetetrazole (PTZ, 6,7,8,9-tetrahydro-5H-tetrazolo[1,5-a] azepine, Sigma-Aldrich, St. Louis, MO, USA), was diluted in saline at concentration of $60 \mathrm{mg} / \mathrm{ml}$ for ip administration at dose of $60 \mathrm{mg} / \mathrm{kg}$ in a volume of 0.1 $\mathrm{ml} / 100 \mathrm{~g}$ of body weight. Saline was used as a control solution for ICV and ip administrations. Diazepam (DZP, Roche, SP, BR) was diluted in Tween 80 (two drops) and saline to a concentration of $10 \mathrm{mg} / \mathrm{ml}$.

Initially, an EEG baseline was recorded for five minutes (b1, Fig 1). The animal was then disconnected from the EEG apparatus, and submitted to ICV administration of different doses of $\mathrm{MgSO}_{4}(32,100$, or $320 \mu \mathrm{g})$ or saline in a volume of $5 \mu \mathrm{l}$ infused over 60 seconds by an injector (made with a 22 GA catheter - Becton, Dickinson Ind. 


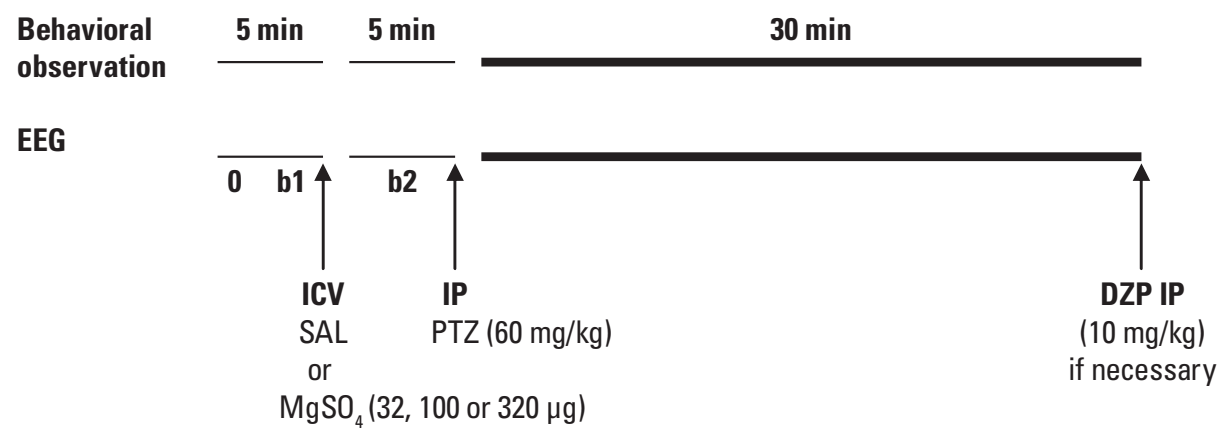

EEG: eletroencephalographic registration; b1: baseline 1; b2: baseline 2; ICV: intracerebroventricular administration; IP: intraperitoneal administration; SAL: saline; PTZ: pentylenotetrazol; $\mathrm{MgSO}_{4}$ : magnesium sulfate; DZP: diazepam.

Fig 1. A schematic representation of the general experimental procedure.

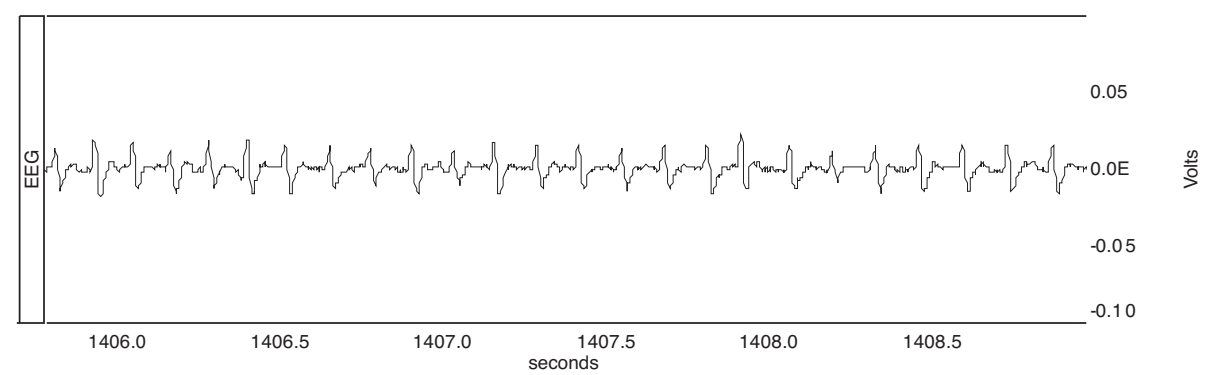

Fig 2. A sample of a bipolar electroencephalographic recording (PT1-PT2), initiating 1406 seconds of the begging of the experimental procedure in a saline treated animal. The recording was during a complex partial seizure, characterized by stereotyped foraging, with ictal paroxysmal patterns of rhythmic sharp-wave activity.

Cirúrgicas Ltda, MG, BR), extending $1 \mathrm{~mm}$ from the cannula connected to a polyethylene cannula (PE 50) attached to a $10 \mu \mathrm{l}$ Hamilton syringe (Stoelting 53431, CO., IL, USA). The order of dosing was counterbalanced by means of a Latin Square design, insuring that all animals did not repeat the same sequence and also compensating for any interference between drug tests. Thus, the animal was reconnected to the EEG apparatus for the recording of a second 5 min EEG baseline (b2, Fig 1). The animal was disconnected briefly for ip administration of PTZ $(60 \mathrm{mg} / \mathrm{kg})$ and returned to the home cage, reconnected to EEG apparatus, and had its behavior and brain electrical activity observed simultaneously for a further 30 minutes (Fig 1).

Diazepam was administered at a dose of $10 \mathrm{mg} / \mathrm{kg}$ ip if the animal was presenting with seizures at the end of the experimental trail (Fig 1). An interval of at least 10 days between experimental trials was utilized to prevent the induction of kindling by $\mathrm{PTZ}^{21}$.

The behavioral observations were conducted by two experimenters, and a third experimenter was designated to control the EEG registration. The type of seizure was determined by an equivalence of EEG changes that characterized different types of seizures and specific behavioral responses induced by PTZ.
Complex partial seizures were characterized by freezing with exophthalmia or stereotyped foraging with no interference by environment stimulus, and were associated with ictal paroxysmal patterns of rhythmic sharpwave activity and/or bursts of slow waves in the EEG (Fig 2). The generalized myoclonic seizures, characterized by subtle and brief muscle contractions, showed simultaneous sequences of polyspikes or polyspike-wave discharges. The generalized tonic seizure was characterized by spastic contractions with the neck and limbs hyperextended showing simultaneous polyspikes of high frequency. Clonic seizures (a series of contractions and relaxations of all four limbs) were related to slow polyspike-waves. Tonic-clonic seizures (strong tonic contractions followed by rhythmic contractions) were associated with progressive increases in spike sequences, which were subsequently replaced by rhythmic polyspikes followed by very slow irregular activity (delta rhythm). Partial seizures followed by a secondary generalization were characterized by rhythmic spike-waves or, sometimes, theta frequency ictal activity followed by a typical EEG pattern for a tonic-clonic seizure.

After the conclusion, animals were anesthetized with chloral hydrate $(400 \mathrm{mg} / \mathrm{kg}$, IP) and received an ICV ad- 
ministration of $5 \mu \mathrm{l}$ of methylene blue $1 \%$ (Biotec, PR, Brazil). They were then deeply anesthetized with chloral hydrate and were intracardially perfused with saline followed by $4 \%$ formaldehyde. Their brains were then removed and maintained in $8 \%$ formaldehyde for at least 48 hours, and were serially sectioned into approximately $80 \mu \mathrm{m}$ slices with a vibratome (serial 1000 Plus - System of Tissue Section, St. Louis, MO, USA). These slices were stained with neutral red and were examined through light microscopy. If the animal died during the experimental trial due to the seizure induced by PTZ, methylene blue $1 \%$ was infused through the cannula and its unperfused brain was removed and roughly examined for the cannula position. In this way, only the animals with the right cannula placement were included for data analysis.

Whenever possible, each animal was submitted to all 4 experimental trials. Animals were divided into the following treatment groups: [1] SAL ( $\mathrm{n}=16)$, [2] $\mathrm{MgSO}_{4}$ $32 \mu \mathrm{g}(\mathrm{n}=16),[3] \mathrm{MgSO}_{4} 100 \mu \mathrm{g}(\mathrm{n}=16)$, and [4] $\mathrm{MgSO}_{4}$ $320 \mu \mathrm{g}(\mathrm{n}=17)$. Therefore, a total of 65 experimental trials were performed. The latency (the time of the onset) for the first seizure (maximum of 1800 seconds), the interval of seizures (the length or window of time between the first and the last seizure) of any seizure type, and the latency and frequency of each seizure type were recorded and expressed as mean \pm s.e.m. Data were analyzed by a one-way analysis of variance (ANOVA) for repeated measures (PTZ dose as a factor) followed by Tukey's test for the determination of the statistically significant differences. A two-tailed alpha level of 0.05 was employed for statistical significance. The software GraphPad Prism 4.0 (La Jolla, CA, USA) was employed for statistical analysis and graphic presentation.

\section{RESULTS}

No behavioral or electroencephalographic changes were observed after the ICV administration of SAL or $\mathrm{MgSO}_{4}$. Seizures were observed in 59 (90.77\%) of 65 experimental sessions performed. Regardless of the type of seizure, the one way ANOVA showed statistically significant differences for the onset of the first behavioral seizure (latency) after PTZ administration among the different doses of $\mathrm{MgSO}_{4}[\mathrm{~F}(3.60)=3.093, \mathrm{p}=0.033]$ compared to treatment with SAL (Fig 3). The post hoc analysis showed that the latency to the first seizure with $\mathrm{MgSO}_{4}$ at $100 \mu \mathrm{g}$ was significantly $(\mathrm{p}<0.05)$ greater compared to the control (SAL ICV followed by PTZ IP) (Fig $3)$. The latency for the first seizure induced by PTZ with the lowest $(32 \mu \mathrm{g})$ or highest $(320 \mu \mathrm{g})$ dose of $\mathrm{MgSO}_{4}$ was not significantly different from the control. These results demonstrated an inverted U-shaped dose-effect curve of $\mathrm{MgSO}_{4}$ on seizures induced by PTZ (Fig 3).

The seizure interval of any seizure type was also dif-

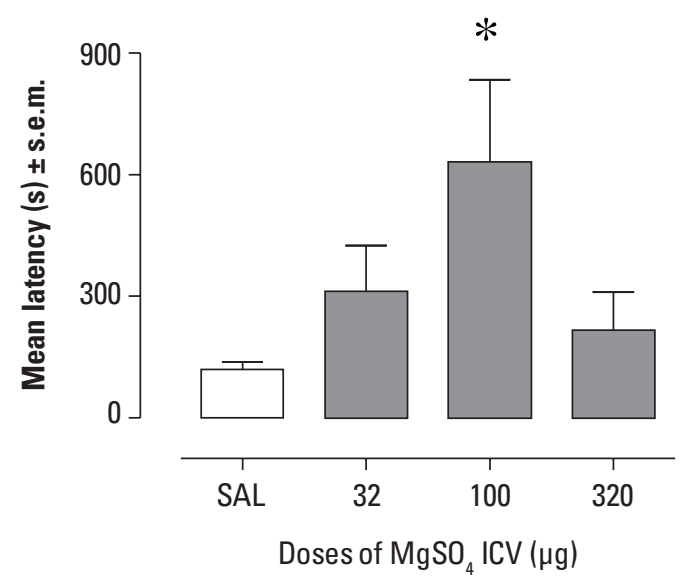

Fig 3. Effects of the intracerebroventricular (ICV) administration of magnesium sulfate $\left(\mathrm{MgSO}_{4}\right.$ at doses of 32,100 , or $\left.320 \mu \mathrm{g}\right)$ or saline (SAL) on the onset (latency) for the first seizure of any type after intraperitoneal administration of pentylenotetrazol (PTZ) at $60 \mathrm{mg} / \mathrm{kg}$. ${ }^{*} \mathrm{p}<0.05$ compared to SAL.

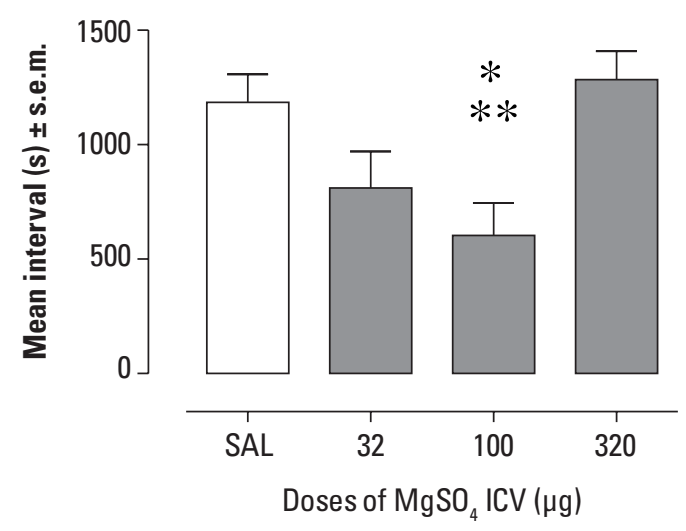

Fig 4. Effects of the intracerebroventricular (ICV) administration of magnesium sulfate $\left(\mathrm{MgSO}_{4}\right.$ at doses of 32,100 , or $320 \mu \mathrm{g}$ ) or saline (SAL) on the length of time between the first and the last seizure (interval of seizures) of any type after intraperitoneal administration of pentylenotetrazol (PTZ) at $60 \mathrm{mg} / \mathrm{kg}$. ${ }^{*} \mathrm{p}<0.05$ and ${ }^{* *} \mathrm{p}<0.01$ compared to SAL and $\mathrm{MgSO}_{4} 320 \mu \mathrm{g}$, respectively.

ferent among the different doses of $\mathrm{MgSO}_{4}[\mathrm{~F}(3.59)=$ 5.119, $\mathrm{p}=0.003$ ] compared to treatments with SAL (Fig 4). This parameter was significantly smaller when $100 \mu \mathrm{g}$ $\mathrm{MgSO}_{4}$ was administered before PTZ compared to the administration of SAL $(\mathrm{p}<0.05)$ or $\mathrm{MgSO}_{4}$ at $320 \mu \mathrm{g}$ $(\mathrm{p}<0.01)$ before PTZ treatment. This parameter showed the opposite pattern observed relative to the latency for the first seizure described above. Thus, it followed a $\mathrm{U}$-shaped dose-response curve for $\mathrm{MgSO}_{4}$ on seizures induced by PTZ (Fig 4).

In individual analyses of each type of seizure, there was also observed an inverted U-shaped pattern for the latency to the first seizure for myoclonic and complex partial seizures induced by PTZ IP (Table). 
Table. Mean latency for the first episode and mean frequency of each seizure type observed after the intracerebroventricular (ICV) administration of magnesium sulfate $\left(\mathrm{MgSO}_{4}\right)$ or saline (SAL) followed by intraperitoneal administration of pentylenotetrazole (PTZ at $60 \mathrm{mg} / \mathrm{kg}$ ).

\begin{tabular}{lcc}
\hline $\begin{array}{l}\text { Seizure type } \\
\text { and ICV doses }\end{array}$ & $\begin{array}{c}\text { Mean latency (s) } \\
\pm \text { s.e.m. }\end{array}$ & $\begin{array}{c}\text { Mean frequency } \\
\pm \text { s.e.m. }\end{array}$ \\
\hline $\begin{array}{l}\text { Tonic } \\
\mathrm{SAL}\end{array}$ & $1719.0 \pm 80.9$ & $0.063 \pm 0.063$ \\
$\mathrm{MgSO}_{4} 32 \mu \mathrm{g}$ & $1800.0 \pm 00.0$ & $0.001 \pm 0.000$ \\
$\mathrm{MgSO}_{4} 100 \mu \mathrm{g}$ & $1633.0 \pm 116.3$ & $0.125 \pm 0.085$ \\
$\mathrm{MgSO}_{4} 320 \mu \mathrm{g}$ & $1504.0 \pm 159.4$ & $0.176 \pm 0.095$ \\
$\mathrm{Clonic}$ & & \\
$\mathrm{SAL}$ & $1301 \pm 191.9$ & $0.38 \pm 0.15$ \\
$\mathrm{MgSO}_{4} 32 \mu \mathrm{g}$ & $1618 \pm 124.4$ & $0.19 \pm 0.14$ \\
$\mathrm{MgSO}_{4} 100 \mu \mathrm{g}$ & $1078 \pm 193.3$ & $0.56 \pm 0.38$ \\
$\mathrm{MgSO}_{4} 320 \mu \mathrm{g}$ & $1595 \pm 140.3$ & $0.19 \pm 0.14$ \\
$\mathrm{Complex} \mathrm{partial}$ & & \\
$\mathrm{SAL}^{\mathrm{MgSO}} 432 \mu \mathrm{g}$ & $1639.0 \pm 110.0 *$ & $0.75 \pm 0.41$ \\
$\mathrm{MgSO}_{4} 100 \mu \mathrm{g}$ & $1364.0 \pm 173.5$ & $0.69 \pm 0.35$ \\
$\mathrm{MgSO}_{4} 320 \mu \mathrm{g}$ & $982.6 \pm 192.1$ & $2.19 \pm 0.67$ \\
\hline * $\mathrm{p}<0.05 \mathrm{compared} \mathrm{to} \mathrm{SAL} \mathrm{or} \mathrm{MgSO}_{4} 320 \mu \mathrm{g}$. &
\end{tabular}

However, the one-way ANOVA only showed statistically significant differences among doses for complex partial seizures $[\mathrm{F}(3.60)=3.894, \mathrm{p}=0.013]$ (Table). The posthoc analysis showed that the latency to the first complex partial seizure was significantly greater $(\mathrm{p}<0.05)$ when the smallest dose of $\mathrm{MgSO}_{4}(32 \mu \mathrm{g})$ was administered ICV before PTZ ip compared to the ICV administration of SAL or $\mathrm{MgSO}_{4}$ at a dose of $320 \mu \mathrm{g}$ before PTZ (Table).

There were no seizures and/or electroencephalographic changes after PTZ administration in 5 sessions with $\mathrm{MgSO}_{4}$ at a dose of $100 \mu \mathrm{g}$ and one with an $\mathrm{MgSO}_{4}$ dose of $32 \mu \mathrm{g}$.

In 5 experimental sessions, animals required ip administration of DZP at the end of the experiment because they continued having seizures. These included two animals after $\mathrm{MgSO}_{4}$ at a dose of $320 \mu \mathrm{g}$, one after SAL, one after $\mathrm{MgSO}_{4}$ at a dose of $32 \mu \mathrm{g}$, and another after a $100 \mu \mathrm{g}$ dose of $\mathrm{MgSO}_{4}$ followed by PTZ ip. Two animals died during the experimental session, both after ICV administration of SAL followed by PTZ IP.

\section{DISCUSSION}

The results of the present study demonstrated that the ICV administration of $\mathrm{MgSO}_{4}$ increased the latency for seizure onset in an inverted U-shaped manner. In addition, $\mathrm{MgSO}_{4}$ administration decreased, in a U-shaped dose-effect curve, the interval of time between the first and the last PTZ-induced seizures in rats, especially at the dose of $100 \mu \mathrm{g}$ in both parameters. This dose of $\mathrm{MgSO}_{4} \mathrm{ICV}$ completely prevented the seizure activity in $31.25 \%$ of the animals.

However, these effects seemed to be more evident for some types of seizures than others. In fact, the lowest dose of $\mathrm{MgSO}_{4}(32 \mu \mathrm{g})$ administered ICV, significantly reduced the latency to the onset of the first complex partial seizure induced by PTZ. It also reduced the latency to the onset of myoclonic seizures, but not to a statistically significant extent. However, the other types of seizures, especially those of generalized patterns such as tonic-clonic, tonic, or clonic, did not seem to be modified by ICV administration of $\mathrm{MgSO}_{4}$.

Furthermore, the highest dose of $\mathrm{MgSO}_{4}(320$ $\mu \mathrm{g}) \mathrm{ICV}$ had no effect. In addition, in some animals it seemed to aggravate the convulsive effects of PTZ.

These results suggest a biphasic profile for $\mathrm{MgSO}_{4}$ effects on seizures induced by PTZ. Therefore, depending on the dose, $\mathrm{MgSO}_{4}$ may have neuroprotective activity because of its anticonvulsive effects. However, high doses of $\mathrm{MgSO}_{4}$ can be either ineffective or pro-convulsive, whereby increasing the convulsive effects of PTZ.

Although paradoxical, a similar biphasic dose-dependent effect has also been reported for traditional antiepileptic drugs ${ }^{22}$. According to Perucca et al. ${ }^{23}$, the ability of antiepileptic drugs to increase seizure activity has been recognized for decades. Phenytoin and vigabatrin seem to aggravate generalized seizures ${ }^{24}$. Benzodiazepines also seem to occasionally precipitate tonic seizures in certain conditions $^{23}$. However, the underlying mechanisms are still poorly understood ${ }^{25}$.

Discarding statistical artifacts, confounding factors, and other problems with the study's design, a U-shaped dose-response relationship can be understood as a specific nonmonotonic function spanning a therapeutic range at low or intermediary doses and a toxic (or causing adverse effects) range at high doses for pharmacologic agents ${ }^{26}$.

One of the most interesting features of U-shaped dose-response relationships concerns the existence of thresholds of effects and the "no-observed-effects levels" ${ }^{26}$ or "zero equivalent points" 27 . These are the doses at which the curve crosses the reference level of a response; that is, doses at which the agent has no effects compared to control treatment.

These characteristics of U-shaped dose-response effects may have accounted for the controversial results of studies previously investigating the effects of magnesium on seizures or epilepsy. For example, Krauss et al. ${ }^{10}$ found that systemic administration of $\mathrm{MgSO}_{4}$ failed to control electroshock and PTZ-induced seizures in mice. These authors observed that peripheral administration of $\mathrm{MgSO}_{4}$ (approximately $6.7 \mathrm{mEq} / \mathrm{kg}$ ) produced adverse ef- 
fects including a profound weakness in all animals characterized by decreased locomotor activity, hypotonia, and abnormal gait. These effects were probably a result of neuromuscular blockade. According to these authors, these peripheral effects might have masked the expression of seizures induced by PTZ because they found EEG activity with evidence of epileptic discharges in $\mathrm{MgSO}_{4}$ treated animals with no behavioral manifestations.

However, Cotton et al. ${ }^{28}$ observed that acute peripheral administration of $\mathrm{MgSO}_{4}(270 \mathrm{mg} / \mathrm{kg})$ significantly increased the latency to the first seizure. It also altered seizure duration induced by an injection of NMDA into the dorsal hippocampus. This effect of $\mathrm{MgSO}_{4}$ was also observed after 2 hours of sustained elevation of serum magnesium levels when compared with saline solutioninjected controls. They also observed that the administration of $\mathrm{MgSO}_{4}(50 \mu \mathrm{g})$ into the dorsal hippocampus also increased the seizure latency period, and prevented seizure activity in $40 \%$ of animals ${ }^{28}$.

Mason et al. ${ }^{19}$ found that $\mathrm{MgSO}_{4}(90 \mathrm{mg} / \mathrm{kg})$ administered intravenously was even more efficacious than phenytoin in reducing NMDA-induced seizures in rats. They also observed that the post-NMDA seizure mortality rate was $50 \%$ in the saline solution controls and $29 \%$ in the phenytoin group, whereas none of the rats that received $\mathrm{MgSO}_{4}$ died.

A similar result was observed in the present study, whereby none of the 32 animals died with the treatment of $\mathrm{MgSO}_{4}$ followed by PTZ. The only two animals that died in status epilepticus during the experiment session were treated with SAL followed by PTZ.

Hallak et al. ${ }^{6}$ observed that systemic administration of $\mathrm{MgSO}_{4}(270 \mathrm{mg} / \mathrm{kg})$ every 4 hours for 24 hours reduced the titrated glutamate binding, whereas long-term administration (every 12 hours for 2 weeks) significantly decreased the titrated glycine binding in many brain regions, suggesting that short-term $\mathrm{MgSO}_{4}$ administration increased the inhibition of the NMDA ion channel.

Hallak et al. ${ }^{29}$ observed that the increased binding of $\left[\mathrm{H}^{3}\right]$-glutamate at NMDA receptor after seizures induced by cortical electrical-stimulation was significantly reduced in rats that received peripheral pre-administration of $\mathrm{MgSO}_{4}$.

The studies of Hallak et al. ${ }^{6,29}$ also suggested that the anticonvulsive effect of $\mathrm{MgSO}_{4}$ may involve, at least in part, NMDA receptor activity in the central nervous system and this might be the mechanism by which $\mathrm{MgSO}_{4}$ administered ICV reduced seizures induced by PTZ in the present study.

The potential neuroprotective effects of $\mathrm{MgSO}_{4}$ have been demonstrated in preclinical studies ${ }^{30}$ and have been suggested to be of importance in some conditions of neural injury with a risk of brain damage ${ }^{31}$.
The results of this study suggest that $\mathrm{MgSO}_{4}$ may also be relevant in the prevention of symptomatic seizures. Nevertheless, the beneficial effects of $\mathrm{MgSO}_{4}$ may depend on the range of doses (high doses may be harmful), and also may depend on the proper time interval between the brain lesion and the initiation of treatment with $\mathrm{MgSO}_{4}{ }^{31}$.

In summary, the present results have demonstrated that ICV administration of $\mathrm{MgSO}_{4}$ reduced PTZ-induced seizures in an inverted U-shaped manner. An intermediate dose $(100 \mu \mathrm{g})$ was the most effective for all seizures types, and the lowest dose $(32 \mu \mathrm{g})$ was effective in reducing the partial complex seizures. These results suggest that, depending on the dose, $\mathrm{MgSO}_{4}$ may be important in prevention of epileptic seizures.

ACKNOWLEDGMENTS - We thank Paula Madeira Sant'Anna and Fellipe Berno Mattos, medicine students of Federal University of Espírito Santo, for their help in collecting data. We also thank Prof. Nian Florêncio da Silva and Mário Armando Dantas for their help with electroencephalographic recordings.

\section{REFERENCES}

1. Olsen R, Avoli M. GABA and epileptogenesis. Epilepsia 1997;38:399-407.

2. Dalby NO, Mody I. The process of epileptogenesis: a pathophysiological approach. Curr Opin Neurol 2001;14:187-192.

3. Crino PB, Jin H, Shumate MD, Robinson MB, Coulter DA, Brooks-Kayal AR. Increased expression of the neuronal glutamate transporter (EAAT3/EAAC1) in hippocampal and neocortical epilepsy. Epilepsia 2002;43:211-218.

4. Köhling R. Voltage-gated sodium channels in epilepsy. Epilepsia 2002;43: 1278-1295.

5. La Roche SM, Helmers SL. The New antiepileptic drugs. JAMA 2004;291: 605-614.

6. Hallak M, Irtenkauf SM, Cotton DB. Fetus-placenta-newborn: effect of magnesium sulfate on excitatory amino acid receptors in the rat brain: I. N-Methyl-D-Aspartate receptor channel complex. Am J Obstet Gynecol 1996;175:575-581.

7. Giblin KA, Blumenfeld H. Is epilepsy a preventable disorder? New evidence from animal models. Neuroscientist 2010;16:253-275.

8. Pitkänen A. Drug-mediated neuroprotection and antiepileptogenesis: animal data. Neurology 2002;59(Suppl 5):S27-S33.

9. Chollet D, Franken P, Raffin $Y$, et al. Magnesium involvement in sleep: genetic and nutritional models. Behav Genet 2001;31:413-425.

10. Krauss GL, Kaplan P, Fisher RS. Parenteral magnesium sulfate fails to control eletroshock and pentylenetetrazol seizures in mice. Epilepsy Res 1989;4:201-206.

11. Euser AG, Cipolla MJ. Magnesium sulfate for the treatment of eclampsia: a brief review. Stroke 2009;40:1169-1175.

12. Ginsberg MD. Neuroprotection for ischemic stroke: past, present and future. Neuropharmacology 2008;55:363-389.

13. Johnston MV. Developmental aspects of epileptogenesis. Epilepsia 1996; 37(Suppl 1):S2-S9.

14. Benga GH, Benga I. Mg, Cu and $\mathrm{Zn}$ in blood and cerebrospinal fluid of epileptic children. J Neurochem 1998;71(Suppl 1):S11.

15. Oladipo OO, Ajala MO, Okubadejo N, Danesi MA, Afonja OA. Plasma magnesium in adult Nigerian patients with epilepsy. Niger Postgrad Med J 2003;10:234-237

16. Yamamoto H, Murakami H, Kamyama N, Miyamoto Y, Fukuda M. Studies on cerebrospinal fluid ionized calcium and magnesium concentrations in convulsive children. Epilepsia 2003;44(Suppl 9):S59.

17. Zou LP, Wang X, Dong CH, Chen CH, Zhao W, Zhao RY. Three-week combination treatment with ACTH + Magnesium sulfate versus ACTH monoterapy for infantile spasms: A 24-week, randomized, open-label, follow-up study in China. Clin Ther 2010;32:692-700. 
18. Link MJ, Anderson RE, Meyer FB. Effects of magnesium sulfate on pentylenetetrazole induced status epilepticus. Epilepsia 1991;32:543-549.

19. Mason BA, Standley CA, Irtenkauf SM, Barducef M, Cotton DB. Magnesium is more efficacious than phenytoin in reducing N-Methyl-D-aspartate seizures in rats. Am J Obstet Gynecol 1994;171:999-1002.

20. Paxinos $G$, Watson $C$. The rat brain in stereotaxic coordinates. $4^{\text {th }}$ ed Orlando: Academic Press, 1998.

21. Ripley TL, Brown G, Dunworth SJ, Stephens DN. Aversive conditioning following repeated withdrawal from ethanol and epileptic kindling. Eur J Neurosci 2003;17:1664-1670.

22. Hirsch $E$, Genton P. Antiepileptic drug-induced pharmacodynamic aggravation of seizures. does valproate have a lower potential? CNS Drugs 2003;17:633-640.

23. Perucca E, Gram L, Avanzini G, Dulac O. Antiepileptic drugs as a cause of worsening seizures. Epilepsia 1998;39:5-17.

24. Gelisse P, Genton P, Kuate C, Pesenti A, Baldy-Moulinier M, Crespel A. Worsening of seizures by oxcarbazepine in juvenile idiophatic generalized epilepsies. Epilepsia 2004; 45:1282-1286.
25. Chaves J, Sander JW. Seizure aggravation in idiopathic generalized epilepsies. Epilepsia 2005;46(Suppl 9):S133-S139.

26. Davis JM, Svendsgaard DJ. U-shaped dose-response curves: their occurrence and implications for risk assessment. J Toxicol Environ Health 1990;30:71-83.

27. Cook R, Calabrese EJ. The Importance of hormesis to public health. Environ Health Perspect 2006;114:1631-1635.

28. Cotton DB, Hallak M, Janusz C, Irtenkauf SM, Berman RF. Central anticonvulsant effects of Magnesium sulfate on N-Methyl-D-aspartate induced seizures. Am J Obstet Gynecol 1993;168:974-978.

29. Hallak M, Hotra JW, Evans JB, Kruger ML. Magnesium inhibits seizure induced rise in N-Methyl-D-aspartate receptor binding in pregnant rat brain. Am J Obstet Gynecol 1999;180(Suppl 1):S45.

30. Faden Al, Bogdan S. Neuroprotection challenges and opportunities. Arch Neurol 2007; 64:794-800

31. Thal SC, Engelhard K, Werner C. New cerebral protection strategies. Curr Opin Anaesthesiol 2005;18:490-495 